\title{
PEREMPUAN NYURLEMBANG DALAM TRADISI MERARIK
}

\author{
Titi Fitrianita, Siti Kholifah, Rabiatul Adawiyah
}

Jurusan Sosiologi, FISIP, Universitas Brawijaya

titifitrianita@gmail.com

\begin{abstract}
Merarik is a tradition which has been maintained by Sasak since a long time. In the beginning, this tradition was an effort to save women from immorality of Anak Agung Made Karangasem, the king of Lombok. But the aim of this tradition started to change. This paper tries to analyze the change of merarik in Nyurlembang Village, Narmada, West Lombok. Using qualitative descriptive and feminist approach, this paper found that merarik causes cultural violence for women. In the middle of the merarik problem, proposal becomes a better alternative for women, but proposal not fully received because it is not their own culture.
\end{abstract}

Keywords: women, Sasak, merarik

\begin{abstract}
Abstrak
Merarik (kawin lari) merupakan tradisi yang dipertahankan sebagian besar Suku Sasak. Awalnya, tradisi ini merupakan upaya menyelamatkan perempuan dari kejahatan Raja Anak Agung Made Karangasem. Namun, seiring waktu tradisi itu berubah. Tulisan ini berupaya untuk melihat perubahan merarik yang terjadi di Dusun Nyurlembang Kecamatan Narmada, Kabupaten Lombok Barat. Menggunakan metode kualitatif deskriptif dan kerangka feminis, terlihat bahwa merarik menyebabkan pelemahan sosial dan budaya terutama pada perempuan dan keluarganya. Meskipun menimbulkan banyak masalah merarik tetap dipertahankan karena demikianlah cara hidup Suku Sasak di Desa Nyurlembang. Di tengah permasalahan itu, muncul alternatif yakni dengan melamar yang menjanjikan cara yang lebih baik namun cara ini belum diterima sepenuhnya karena merarik dianggap budaya leluhur Suku Sasak.
\end{abstract}

Kata Kunci: merarik, women, Sasak 


\section{PENDAHULUAN}

Pada banyak budaya, pernikahan menjadi satu proses kehidupan yang berarti karena lewat pernikahanlah kehidupan baru ditandai dan kedewasaan penuh diperoleh laki-laki dan perempuan. Sebelum pernikahan itu sendiri terdapat prosesi atau ritual yang berbeda antara satu budaya dengan budaya yang lainnya. Sudiyat (Parlindungan, 2004: 20-22) mencatat 3 proses menuju pernikahan yang biasa terjadi yaitu lamaran, perkawinan lari bersama, dan kawin lari. Lamaran dan kawin lari adalah dua proses menuju pernikahan yang lebih banyak dikenal di Indonesia.

Suku-suku di Indonesia lebih banyak menggunakan lamaran sebelum pernikahan. Namun, kawin lari sebelum pernikahan sesungguhnya juga mendapatkan tempat di Indonesia. Masyarakat Suku Lampung Pepadun, misalnya, melakukan kawin lari semambang sebagai alternatif untuk menghindari proses lamaran yang memakan banyak biaya terkait dengan syarat pembayaran, pembiayaan, dan upacara perkawinan yang diminta oleh pihak perempuan. Meskipun kawin lari ini sah secara adat namun cara ini tidak dibenarkan oleh adat (Parlindungan, 2004: 47).

Berbeda dengan Suku Lampung Pepadun, kawin lari justru adalah bagian adat yang sah dan harus untuk dilakukan oleh Suku Sasak. Dalam budaya Sasak sendiri secara adat tidak mengenal konsep lamaran. Jika kawin lari di Suku Lampung Pepadun adalah upaya yang dilakukan oleh laki-laki karena tidak mampu memenuhi syarat adat yang ditentukan (Parlindungan, 2004: 67), kawin lari Suku Sasak justru dianggap sebagai ajang pembuktian kualitas laki-laki-keberanian, kehebatan, dan kejantanan (Adnan, 2004: 59).

Kawin lari disebut merarik oleh Suku Sasak. Merarik diawali dengan membawa lari calon mempelai perempuan oleh calon mempelai laki-laki pada waktu malam hari berlangsung setelah Mahgrib, secara diam-diam keluar dari rumahnya, tanpa sepengetahuan kedua orang tua calon mempelai perempuan. Pemuda-pemudi Sasak biasanya memanfaatkan momen wisata dan rekreasi setelah lebaran untuk pergi merarik, karena cara ini lebih mudah daripada harus melarikan anak gadis dari rumahnya.

Tidak jarang perempuan yang dibawa merarik masih belia, baru lulus SMA, atau di usia kurang dari 18 tahun dimana mereka belum memiliki persiapan untuk melangsungkan pernikahan. Akibatnya banyak terjadi pernikahan dini pada perempuan sehingga berpengaruh pada ketidaksiapan psikologis pasangan terutama bagi perempuan untuk membina sebuah keluarga hingga pada akhirnya menyebabkan terjadinya banyak perceraian pada masyarakat Suku Sasak.

Merarik yang dilaksanakan mendadak dan tanpa perencanaan yang matang menyebabkan keluarga kedua calon mempelai harus mempersiapkan acara pernikahan dalam waktu yang singkat segera setelah merarik dilakukan sehingga tidak jarang menimbulkan konflik antar keluarga. Meskipun merarik meninggalkan kesan negatif pada sebagian masyarakat (Aniq, 2013: 2322) namun merarik tetap dipertahankan karena konsep kesetiaan terhadap tradisi Suku Sasak (Adnan, 2004: 64). 
Artikel ini berusaha untuk menganalisis praktik merarik yang terjadi di Desa Nyurlembang, Narmada, Lombok Barat, dimana hampir keseluruhan warga melakukan merarik. Penelitian mengenai praktik merarik sebenarnya telah dilakukan oleh Adnan. Adnan (2004: 4) melacak praktik merarik di Kecamatan Ampenan, Kota Mataram. Kecamatan Ampenan secara kultural adalah sebuah kota provinsi yang terbuka dengan banyak perubahan. Suku Sasak yang tinggal di kota ini sudah mulai menerima lamaran dan meninggalkan tradisi merarik. Sedangkan Suku Sasak di pedesaan masih menganggap tabu istilah lamaran dan cenderung lambat menanggapi perubahan.

Penelitian ini melengkapi penelitian yang telah dilakukan oleh Adnan. Jika Adnan lebih banyak menggali data praktik merarik di kota, penelitian ini lebih banyak berfokus pada praktik merarik yang ada di pedesaan jauh dari pusat kota dimana masyarakat di Dusun Nyurlembang masih begitu kuat memegang tradisi termasuk melakukan merarik.

\section{METODE PENELITIAN}

Penelitian ini menggunakan metode kualitatif deskriptif. Data diambil dengan menggunakan wawancara secara mendalam kepada 7 orang informan dengan kriteria warga Desa Nyurlembang, baik perempuan maupun laki-laki yang telah melangsungkan pernikahan baik dengan melalui proses merarik ataupun lamaran, observasi non partisipan, dan data sekunder berupa dokumentasi, buku, artikel, dan lain-lain yang mendukung penelitian. Analisis data menggunakan analisis induktif dan keabsahan data menggunakan metode triangulasi.

\section{MERARIK DALAM TRADISI SASAK}

Secara etimologis, merarik berasal dari kata lari dalam bahasa Suku Sasak. Merarinang berarti melaiang atau dalam bahasa Indonesia melarikan, yaitu laki-laki melarikan perempuan untuk dijadikan isteri (Saladin, 2013: 23). Istilah merarik yang diartikan sebagai kawin lari menyebar di seluruh Pulau Lombok meskipun di beberapa tempat istilah tersebut berbeda karena perbedaan logat setiap desa yang memiliki keragaman jenis pengucapan.

Merarikmerupakan budaya khas Suku Sasak dalam memulai memilih pasangan untuk dinikahi dan awal membangun keluarga. Praktik ini tersebar di seluruh Pulau Lombok namun di beberapa tempat terdapat penyebutan berbeda atas istilah merarik ini. Di Kecamatan Ampenan, Suku Sasak memberikan istilah marari (Adnan, 2004: 2). Ada pula yang menyebutnya kerarikan. Sedangkan Suku Sasak di Desa Nyurlembang mayoritas menyebut merarik. Aniq (2013: 2324) menjelaskan merarik berikut ini:

Kawin lari biasanya diartikan sebagai bentuk perkawinan yang tidak didasarkan atas persetujuan lamaran orang tua, tetapi berdasarkan kemauan sepihak atau kedua belah pihak dari sepasang pemuda dan pemudi sebagai jalan keluar bagi mereka untuk menikah. Namun dalam tradisi masyarakat Sasak dimana tradisi kawin lari dikenal dengan merarik, kawin lari memiliki 
pemaknaan yang khas. Masyarakat Sasak mengartikan merarik sebagai proses pernikahan yang didahului dengan membawa lari atau "menculik" seorang gadis sebelum prosesi pernikahan secara agama dan hukum nasional dilaksanakan. Istilah merarik sendiri berasal dari kata dalam bahasa Sasak. Ada beberapa pendapat mengenai asal kata merarik, di antaranya; "berari" yang berarti berlari. Yaitu seorang lelaki membawa lari seorang gadis untuk dinikahi. Makna inilah yang kemudian berkembang menjadi istilah merarik yaitu sebuah tindakan yang dilakukan untuk membebaskan si gadis dari ikatan orang tua serta keluarganya.

Merarik awalnya adalah istilah Suku Sasak yang digunakan untuk menyebut tindakan membawa lari gadis dengan maksud untuk dinikahi. Dalam perkembangan selanjutnya merarik mengalami perluasan makna dan digunakan untuk menyebutkan seluruh rangkaian pernikahan dalam Suku Sasak. Hal tersebut terlihat misalnya dalam percakapan sehari-hari Suku Sasak untuk menanyakan seseorang sudah menikah ataukah belum dengan cukup bertanya apakah yang bersangkutan sudah merarik ataukah belum (Aniq, 2013: 2325).

Tradisi kawin lari atau merarik merupakan tradisi Suku Sasak yang didapatkan secara turun temurun yang menjadi awal proses pernikahan. Dalam tradisi ini seorang pemuda melarikan atau menculik anak gadis yang akan dijadikan calon istri. Merarik merupakan pertanda awal ritual perkawinan yang dilakukan hanya pada malam hari dan biasanya dilakukan setelah Mahgrib. Tidak diperbolehkan secara adat melakukan merarik pada siang hari. Jika merarik dilangsungkan pada siang hari, sanksi adat akan diberikan. Selain itu, pasangan yang melakukan merarik pada siang hari dianggap tidak memiliki nyali besar sehingga pasangan yang melakukan merarik mendapatkan bukan hanya sanksi adat namun juga sanksi sosial berupa gunjingan atau sindiran.

Sebelum merarik dilangsungkan biasanya sepasang muda mudi telah lebih dahulu bersepakat jam dan hari melakukan merarik. Dengan demikian, merarik menjadi rahasia yang hanya pasangan yang bersepakat itulah yang mengetahuinya. Proses ini dirahasiakan dari kedua orang tua calon mempelai untuk mencegah pembatalan merarik. Sang gadis lantas dilarikan ke tempat keluarga calon suami yang jauh dari desa atau dusun si gadis dan atau dusun calon suaminya (Daliem, 1981: 27).

Dalam tradisi merarik ada beberapa tahap adat yang harus dilakukan. Pertama, midang merupakan proses pendekatan dimana seorang pemuda datang ke rumah perempuan. Biasanya kunjungan ini dilakukan pada malam Kamis dan malam Minggu. Kedua, merarik yaitu proses dimana laki-laki dan perempuan mengadakan perjanjian untuk bertemu kemudian bersembunyi di penyeboan (tempat persembunyian yang dimiliki oleh keluarga atau kerabat dekat pihak laki-laki). Ketiga, selabar dan majetik merupakan proses dimana keluarga pihak laki-laki melaporkan kepada kepada dusun asal calon pengantin perempuan dan pemberitahuan kepada pihak keluarga perempuan bahwa anak laki-laki mereka telah melakukan merarik dengan anak perempuan mereka. Dalam proses ini terjadi perundingan untuk 
membuat kesepakatan menentukan proses adat selanjutnya yaitu ijab kabul, sorong serah, dan nyongkolan.

Keempat, mbait wali yaitu proses menjemput wali untuk menikahan perempuan pada saat pelaksanaan ijab kabul. Kelima, aji karma atau sorong serah yaitu prosesi simbol untuk memberi dan menerima pengantin di dalam perkawinan. Keenam, nyongkolan yaitu iring-iringan keluarga laki-laki menuju keluarga perempuan yang diiringi dengan alunan musik tradisional Suku Sasak yang disebut gendang beleq. Prosesi keenam ini adalah prosesi terakhir dari keseluruhan ritual adat merarik.

\section{SEJARAH MERARIK}

Ada dua pendapat mengenai asal asul merarik. Pendapat pertama menyatakan merarik merupakan tradisi asli Suku Sasak jauh sebelum Bali melakukan invansi dan penguasaan Lombok pada tahun 1740 dan melakukan penguasaan selama 100 tahun. Pendapat kedua menyatakan bahwa merarik merupakan tradisi hasil pengaruh Bali karena Suku Sasak pernah dijajah dalam waktu yang cukup lama (Aniq, 2012: 2325). Pendapat pertama terangkum dalam cerita berikut.

Bali pernah menjajah Lombok khususnya Lombok bagian barat. Narmada sebagai salah satu kecamatan yang ada di daerah Lombok Barat merupakan salah satu pusat kekuasaan Bali pada masa itu. Kolonial Bali (Anak Agung) yang datang ke Lombok pada masa itu juga mempraktikan budaya kawin lari bahkan merupakan adat yang sudah dijalankan oleh para leluhur mereka beserta dengan masyarakatnya (Saladin, 2013: 27). Berdasarkan cerita dari masyarakat Desa Nyurlembang, mengenai masa kekuasaan Anak Agung. Anak Agung banyak melakukan penindasan terhadap masyarakat Sasak.

Salah satu bentuk penindasan Anak Agung ialah ia mengutus para prajuritnya untuk mengumpulkan para gadis yang masih lajang atau belum menikah untuk dikumpulkan di Telage Beleq (sebuah telaga yang berada di dalam Taman Narmada). Semua gadis dikumpulkan setelah itu para gadis diharuskan untuk mandi di Telaga Belek dalam keadaan telanjang. Anak Agung Made Karangasem selanjutnya tinggal menunjuk gadis mana yang ingin ditidurinya.

Anak Agung Made Karangasem tidak segan-segan mengutus prajuritnya untuk membunuh gadis tersebut apabila melakukan penolakan. Kesewenangwenangan Anak Agung Made Karangasem mendorong orang tua Suku Sasak pada masa itu untuk meminta anaknya menikah dengan pasangan yang dicintainya dengan cara melarikan diri karena tidak ingin anaknya menjadi korban kesewenang-wenangan Anak Agung.

Suku Bali yang beragama Hindu dipercaya memberikan pengaruh yang besar pada Suku Sasak selama periode penguasaannya tersebut. Unsur kebudayaan Bali dalam bentuk kebiasaan, bahasa, kesenian, dan kerajinan melebur dengan budaya Suku Sasak. Pendatang dari Pulau Bali yang sudah tinggal, dan menetap di Lombok selama ratusan tahun menempati daerah-daerah di sekitar Mataram, Cakranegara, Ampenan dan Narmada. Peleburan budaya lebih terlihat di Lombok Barat karena Suku Bali yang tinggal di Lombok Barat lebih 
kuat memegang adat istiadat asalnya dibandingkan Suku Bali yang tinggal di Pulau Bali (Amin, 1997: 35).

Tradisi kawin lari yang dilakukan oleh Suku Sasak dipercaya berasal dari adopsi tradisi kawin lari Suku Bali yang datang ke Lombok pada masa itu. Tekanan pemerintahan Anak Agung membuat adopsi tradisi kawin lari tersebut semakin mengkristal. Pendapat lain terkait asal usul tradisi kawin lari menyebutkan bahwa kawin lari merupakan tradisi milik asli Suku Sasak yang telah dipraktekkan jauh sebelum Bali datang ke Lombok. Dalam perkembangan selanjutnya, tradisi kawin lari yang disebut sebagai tradisi asli Suku Sasak mengalami peleburan dengan agama Islam yang masuk ke Pulau Lombok di kemudian hari.

Pendapat lain terkait asal usul tradisi kawin lari menyebutkan bahwa kawin lari merupakan tradisi milik asli Suku Sasak yang telah dipraktekkan jauh sebelum Bali datang ke Lombok. Dalam perkembangan selanjutnya, tradisi kawin lari yang disebut sebagai tradisi asli Suku Sasak mengalami akulturasi dengan agama Islam yang masuk ke Pulau Lombok di kemudian hari. Suku Sasak yang beragama Islam, diharuskan untuk mengucapkan ijab kabul terlebih dahulu sesuai ketentuan syariat Islam barulah pasangan diperbolehkan untuk tinggal bersama. Selama pasangan belum menikah menurut ketentuan agama, mereka tidak diperbolehkan tinggal bersama untuk menghindari hubungan seksual di luar pernikahan yang sering disebut zina.

\section{PRAKTIK MERARIK SETELAH BERAKHIRNYA OKUPASI BALI}

Setelah kekuasaan Raja Bali runtuh Lombok dijajah oleh Belanda pada abad 19 (1984). Penjajahan Belanda tidak menyebabkan perubahan praktik kawin lari. Kawin lari tetap berlangsung di Lombok bahkan praktik kawin lari menyebabkan perempuan Suku Sasak jauh lebih terdominasi dibandingkan masa sebelumnya. Kawin lari banyak dilakukan tanpa kesepakatan si perempuan. Banyak pernikahan terjadi karena perempuan dibawa lari begitu saja dan hanya berdasarkan keinginan laki-laki. Cara yang dilakukanpun sangat memaksa perempuan. Perempuan dipaksa untuk dibawa lari dan mendapatkan kekerasan ketika merarik dilangsungkan. Pada masa itu laki-laki bekerja sama untuk membantu temannya membawa lari perempuan yang ingin dinikahinya. Praktik kawin lari semacam ini tidak jelas kapan awal mulanya namun di Desa Nyurlembang praktik ini berakhir hingga sekitar tahun 1980an. Muncul kesadaran di antara lakilaki dan perempuan Suku Sasak bahwa menkah harus didasarkan atas keinginan diri sendiri, bukan karena paksaan. Hak individu atas pemilihan pasangan menjadi lebih kuat dibandingkan sebelum tahun 1980-an.

Ye tetep jari dakak ne ngamok, missal lek pesebokan, arak dateng dukun misalne, adekne ngakah ngamok, laek secare adat amun nengke kan ngkah ne berlaku sengenono. Mun nengke ye lekakan dirik doang nengke (Pernikahan pasti akan tetap terjadi, misalkan pada saat 
berada di tempat persembunyian, akan didatangkan dukun agar calon pengantin perempuan tidak mengamuk, tapi itu dulu, untuk sekarang cara seperti itu sudah tidak berlaku. Untuk saat ini mereka tidak dipaksakan tetapi berdasarkan keinginan sendiri) (wawancara dengan Sudarman, 23 Agustus 2015).

Merarik merupakan sebuah proses mengawali perkawinan yang berprinsip pada kebebasan bagi laki-laki atau perempuan Suku Sasak dalam memilih pasangan mereka terutama setelah tahun 1980-an. Midang memungkinkan orang tua perempuan untuk mengetahui lakilaki mana saja yang sedang mendekati anak perempuannya yang berpotensi menjadi menantu mereka. Dari midang inilah biasanya perempuan Suku Sasak memilih laki-laki yang ia inginkan untuk menjadi calon suaminya dan merencakan merarik tanpa sepengetahuan orang tua perempuan karena demikianlah yang diharuskan di dalam adat. Adnan (2004: 50) menyebutkan bahwa midang merupakan bentuk kebebasan perempuan karena di tangannyalah pilihan merarik dengan laki-laki yang ia inginkan ditetapkan.

Merarik merupakan proses pembuktian bahwa sebagai laki-laki Sasak bahwa ia memperjuangkan perempuan yang mereka cintai dengan sepenuh hati karena dia harus menantang bahaya melarikan anak perempuan tanpa pengetahuan orang tua. Sementara bagi perempuan Suku Sasak merarik adalah proses dimana dirinya merasa tersanjung karena telah diperjuangkan oleh laki-laki yang menginginkannya dan menandakan kekuatan dirinya sendiri dalam memilih pasangan yang ia inginkan lepas dari keinginan orang tua.

Sekilas perempuan Sasak terlihat memiliki kekuasaan yang berimbang dengan laki-laki Sasak dalam proses midang apalagi jika merarik adalah kesepakatan kedua belah pihak. Namun, segera setelah merarik berlangsung, superioritas laki-laki dan inferioritas perempuan menjadi sangat nyata. Hal ini terlihatdalamkeseluruhan praktikmerarik dari merarik itu sendiri hingga nyongkolan hingga berujung ketika kehidupan rumah tangga yang sebenarnya dimulai. Patriarki adalah logika budaya yang tidak hanya dianut oleh laki-laki Suku Sasak namun juga dipertahankan oleh perempuan Suku Sasak itu sendiri lewat merarik. Demikianlah yang terjadi di Desa Nyurlembang.

\section{DESA NYURLEMBANG}

Desa Nyurlembang secara administratif berada di Kecamatan Narmada Kabupaten Lombok Barat Provinsi Nusa Tenggara Barat. Desa ini terdiri dari 4 dusun yaitu Nyurlembang Daye, Nyurlembang Barat, Telaga Ngembeng, dan Tatar. Total pendatang di Desa Nyurlembang sebanyak 1,4\% dari jumlah total keseluruhan penduduk sebanyak 3.588 jiwa. Pendatang terbesar dari Bali yaitu sebanyak 1,3\%, sementara sisanya masing-masing $1 \%$ pendatang dari Suku Mbojo, dan Samawa. Penduduk terbesar adalah Suku Sasak yaitu sebanyak $98,4 \%$ dari total jumlah penduduk di Desa Nyurlembang. Berikut adalah tabel etnis penduduk Desa Nyurlembang, Berdasarkan profil Desa Nyurlembang tahun 2014. 
Gambar 1. Penduduk Desa Nyurlembang Berdasarkan Etnis

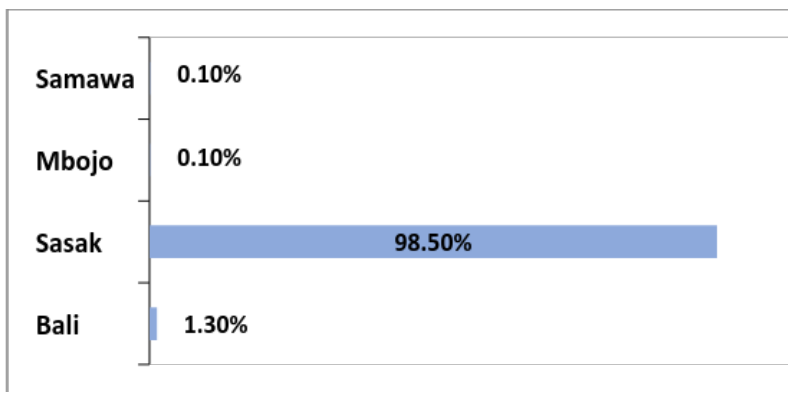

Sumber: Profil Desa Nyurlembang, 2014

Terdapat 3 agama yang dianut oleh masyarakat Suku Sasak yang tinggal di Desa Nyurlembang, yaitu Agama Islam, Agama Hindu, dan Agama Kristen. Penganut Agama Islam adalah yang terbanyak di Desa Nyurlembang yaitu sebanyak 98,5\%, Kristen 0,2\%, dan Hindu sebanyak 1,3\%. Masyarakat yang beragama Hindu sekaligus merupakan pendatang dari Bali.

Komposisi penduduk Desa Nyurlembang dimana mayoritas adalah Suku Sasak dan beragama Islam menjadi faktor yang sangat menentukan dalam bertahannya praktik merarik. Merarik adalah budaya yang tidak bisa dipisahkan dari Suku Sasak. Menjadi Suku Sasak berarti harus melestarikan budaya merarik. Oleh karena itulah, mayoritas Suku Sasak yang tinggal di Desa Nyurlembang mempraktikkan merarik.

Lamaran yang mulai menjadi hal yang biasa untuk dilakukan di daerah kota seperti Mataram dan Ampenan nyatanya masih menjadi hal yang tabu untuk dilakukan di Desa Nyurlembang. Masyarakat di Desa Nyurlembang masih memiliki anggapan yang kuat bahwa melamar sama halnya dengan meminta anak gadis. Melakukan lamaran sama saja memperjual belikan anak ayam yang bisa diperjual belikan begitu saja, "memang anak saya anak ayam yang bisa diperjual belikan begitu saja" begitulah anggapan masyarakat mengenai lamaran (Daliem, 1982: 30). Bagi mereka, anak perempuan haruslah diperjuangkan oleh laki-laki seperti di dalam proses merarik. Maka, merarik adalah cara yang tepat dan cara yang diharapkan dilakukan oleh orang tua kepada anak-anak mereka meskipun praktik merarik menimbulkan banyak konflik.

\section{PRAKRIT MERARIK SUKU SASAK DESA NYURLEMBANG}

Dalam pembicaraan sehari-hari masyarakat di Desa Nyurlembang, merarik merupakan salah satu bahasan yang sering diperbincangkan. Kejadiankejadian di seputar merarik adalah cerita yang selalu hidup dalam kehidupan keseharian di Desa Nyurlembang. Hal ini menunjukkan bahwa merarik merupakan kenyataan kultural yang secara objektif hadir dan penting di dalam kehidupan Suku Sasak di Desa Nyurlembang.

Merarik bagi laki-laki Suku Sasak adalah proses budaya yang sangat penting. Kebanyakan masyarakat Suku Sasak menjelaskan bahwa merarik pada umumnya secara kultural dapat dianggap sebagai cara yang disepakati laki-laki untuk membuktikan kelaki-lakiannya (Adnan, 2004: 59) dan menunjukkan harga diri seorang laki-laki. Pendapat semacam ini juga ditemukan pada masyarakat Desa Nyurlembang.

Merarik merupakan adat yang harus dilakukan sebagai upaya untuk menghargai keluarga perempuan. Hal tersebut berhubungan dengan adanya 
pesuke yang harus dibayarkan oleh keluarga laki-laki kepada keluarga perempuan. Bagi Suku Sasak sangat tidak sopan apabila "harga" perempuan langsung dibicarakan seperti yang dilakukan apabila lamaran dilakukan. Padahal penentuan pesuke terindikasi sebagai proses komersialisasi perempuan (Aniq, 2012: 2331). Hal ini terindikasi dari semakin tinggi tingkat status sosial, budaya, dan ekonomi keluarga perempuan, pesuke yang diminta juga akan semakin tinggi. Jenis pekerjaan dan pendidikan perempuan yang melakukan merarik juga menjadi faktor penentu besaran pesuke yang harus dibayarkan, semakin tinggi prestise jenis pekerjaan dan semakin tinggi tingkat pendidikan yang dimiliki perempuan, pesuke yang dibayarkan pun akan lebih tinggi (Haq \& Hamdi, 2016: 165).

Kondisi di atas seiring dengan tuntutan budaya yang dibebankan kepada laki-laki Suku Sasak. Murdan (2015: 104) menyebutkan istilah yang lazim di Suku Sasak "jika seseorang mempunyai anak laki-laki kemudian dia menikah, maka dia akan membuat 2 taring (tenda pesta pernikahan) yakni di rumahnya sendiri (begawe) dan di rumah $\mathrm{ibu} /$ bapak istrinya (mentoak)". Dengan demikian beban ekonomi keluarga laki-laki jauh lebih besar dibandingkan keluarga perempuan ketika merarik dilakukan. Maka, idealnya, laki-laki (dan keluarganya) yang melakukan merarik memiliki kemampuan ekonomi yang cukup atau lebih untuk menanggung semua tanggungjawab budaya yang harus dilakukannya setelah mengajak seorang perempuan merarik.

Konsep merarik yang demikian diturunkan dari satu generasi ke generasi selanjutnya dan membuat merarik menjadi praktik yang paling benar untuk dilakukan untuk mengawali pembentukan sebuah keluarga. Dalam proses tersebut keluarga memainkan peranan penting dalam proses internalisasi (Rabiatul, 2016: 87). Ketika mayoritas orang tua melakukan merarik sebagai awal proses membangun sebuah keluarga maka anak-anak mereka juga diharapkan melakukan hal yang sama. Keluarga dengan demikian menjadi agen yang sangat penting dalam menanamkan dan memastikan kepatuhan budaya Sasak pada generasi selanjutnya.

Laki-laki dan perempuan di Desa Nyurlembang lahir dan tumbuh dalam budaya Sasak dan sedikit mendapatkan alternatif berkehidupan di luar budaya yang telah dikenal seumur hidupnya. Kalaupun alternatif berkehidupan dikenal lewat hadirnya teknologi dan informasi terutama akses terhadapa media sosial namun ikatan-ikatan budaya yang ada rupanya tidak mudah untuk dilepaskan. Kuatnya praktik merarik yang diinternalisasikan dari satu generasi ke generasi diikuti dengan harapan dari orang tua agar anaknya menikah dengan sesama Suku Sasak sehingga identitas sebagai orang Sasak bertahan.

Internalisasi kepatuhan budaya selanjutnya ditegakkan oleh masyarakat terutama kepada laki-laki dan perempuan yang menginjak remaja atau dewasa yang berpotensi untuk melakukan merarik. Masyarakat melakukan pengawasan lebih kepada laki-laki yang datang ke rumah perempuan pada malam hari terutama yang melebihi kepantasan waktu berkunjung. Biasanya masyarakat (tetangga dekat) akan menyebut laki-laki tersebut berpacaran dengan perempuan 
yang rumahnya ia datangi. Ketika masyarakat telah menyebut laki-laki dan perempuan tersebut berpacaran pengawasan kepada masyarakat kepada keduanya lebih ketat untuk menghindarkan mereka melakukan perbuatan yang tidak pantas dilakukan oleh pasangan yang belum menikah terutama berhubungan seksual karena agama Islam tidak memperbolehkan zina.

Tingginya tingkat pendidikan Suku Sasak di Desa Nyurlembang rupanya juga tidak berpengaruh secara signifikan pada perubahan praktik merarik. Berikut ini tabel tingkat pendidikan masyarakat di Desa Nyurlembang.

\section{Gambar 2. Penduduk Desa Nyurlembang Berdasarkan Tingkat Pendidikan}

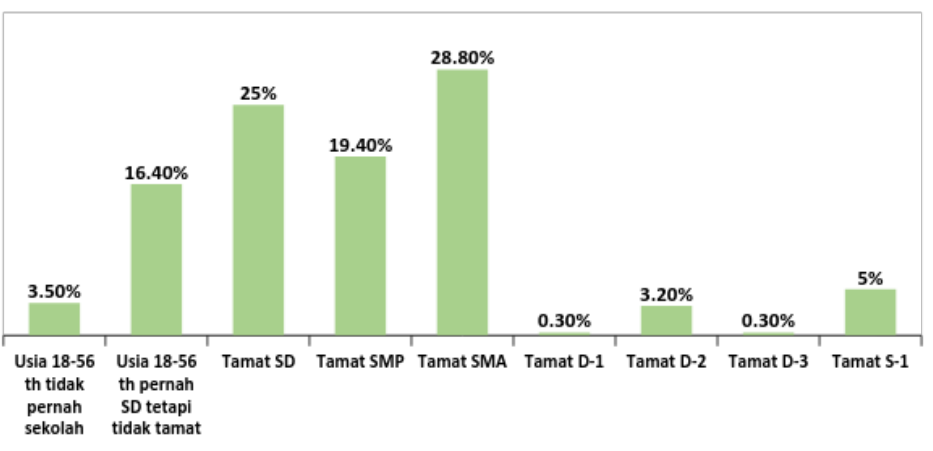

Sumber: Profil Desa Nyurlembang, 2014

Dari tabel di atas prosentase tingkat pendidikan menengah (SMA) merupakan prosentase paling tinggi yakni sebesar 28,8\% dari total jumlah penduduk 1.901 jiwa pada tahun 2014. Sedangkan total jumlah tingkat pendidikan tinggi D1/D2/ D3/S1 sebesar 8,8\%. Data di atas tidak menyebutkan lokasi institusi pendidikan tinggi yang menjadi tempat bagi 127 orang menyelesaikan pendidikan tingginya. Bila dikaitkan antara tidak tersedianya data nama institusi pendidikan tinggi yang telah ditempuh oleh masyarakat Desa Nyurlembang dan tidak adanya korelasi antara tingginya tingkat pendidikan dengan perubahan tradisi merarik maka muncul 2 alasan mengapa hal tersebut bisa terjadi.

Pertama, masyarakat Desa Nyurlembang menyelesaikan pendidikan tingginya diLombok seperti diUniversitas Mataram, dll. yang secara kultural masih kental dengan budaya Sasak sehingga merarik tetap menjadi pilihan utama untuk memulai berkeluarga. Kedua, beberapa pemuda/i Sasak memilih untuk mendapatkan pendidikan tingginya di luar Lombok seperti di Pulau Jawa yang menjadi pusat pendidikan di Indonesia. Namun, ketika kembali ke Lombok, harapan orang tua kepada mereka untuk menikah dengan sesama Suku Sasak masih kuat. Kewajiban berbakti kepada kedua orang tua dengan memenuhi harapan mereka merupakan hal yang dijunjung tinggi di dalam Islam (Platt, 2012: 174) dan menjadi faktor paling utama anak memutuskan untuk merarik atau tidak.

Ketika seorang anak memutuskan untuk mengikuti harapan orang tua dengan menikahi sesama Suku Sasak secara otomatis mereka diharapkan melakukan merarik sebagai tradisi yang sah dan harus dilakukan sebagai Suku Sasak. Menikahkan anaknya dengan orang luar Suku Sasak tidak pernah menjadi pilihan utama orang tua karena tradisi merarik menjadi begitu cair dan budaya yang telah ditetapkan menjadi kabur (Murdan, 2015: 138). Harapan agar tidak menikah dengan orang luar Suku Sasak merupakan 
usaha melanggengkan struktur dan pranata budaya yang telah beratus tahun lamanya menjadi pegangan Suku Sasak di Desa Nyurlembang. Namun demikian, tradisi merarik rupanya tidak kebal terhadap perubahan. Beberapa unsur di dalam merarik berubah seiring perubahan di masyarakat yang lebih luas. Berikut beberapa perubahan praktik merarik di Desa Nyurlembang.

Tradisi midang yang awalnya selalu dilakukan dengan cara mendatangi rumah perempuan Suku Sasak perlahan mulai bergeser dan digantikan oleh teknologi. Gaya komunikasi tatap muka antara laki-laki dan perempuan terfasilitasi lewat hadirnya telepon pintar yang memungkinkan keduanya berkomunikasi tatap muka jarak jauh. Rencana merarik bagi pasangan laki-laki dan perempuan yang telah menjalin hubungan percintaan cukup dilakukan dengan perantaraan telepon pintar ini tanpa harus hadir secara langsung di rumah keluarga perempuan. Kehadiran teknologi terutama akses terhadap internet rupanya telah mengaburkan pengawasan masyarakat atas pergaulan laki-laki dan perempuan karena ketidakmampuan sistem pengawasan tersebut dalam menjangkau pergaulan keduanya di dunia maya lewat perantaraan teknologi. Dengan demikian laki-laki dan perempuan Suku Sasak bisa merencanakan merarik kapan saja, pada usia berapapun, dengan status sosial dan ekonomi manapun.

Hadirnya teknologi tidak hanya mengubah cara midang dilangsungkan namun juga ketika merarik dilaksanakan. Pada saat merarik berlangsung beberapa perempuan yang melakukan merarik menghubungi keluarga mereka melalui telepon dan mengabarkan bahwa mereka telah merarik namun merahasiakan tempat persembunyiannya. Sesaat setelah mengabarkan merarik telepon tersebut dimatikan dengan tujuan menghindari orang tua mengontak kembali anak perempuannya dan menghindari penolakan orang tua atas merarik yang dilakukan anak perempuannya dengan berbagai macam alasan salah satunya adalah tidak menyetujui laki-laki yang akan menjadi menantunya.

Sebelum telepon hadir dan meluas penggunaannya pemilik rumah yang menjadi tempat persembunyian biasanya menjadi orang yang bertugas mengabarkan kepada kepala dusun setempat bahwa ada pasangan yang melakukan merarik (selabar). Setelah itu kepala dusun lokasi persembunyian akan menghubungi kepala dusun keluarga perempuan yang nantinya akan mengabarkan secara resmi kepada keluarga perempuan bahwa anak perempuan mereka melakukan merarik (majetik).

Hadirnya teknologi berupa telepon memungkinkan orang tua perempuan di Desa Nyurlembang mengetahui lebih awal informasi merarik yang dilakukan oleh anaknya sebelum mendapatkan pernyataan resmi dari kepada dusun yang secara adat memiliki tugas untuk mengabarkan merarik kepada keluarga perempuan. Namun demikian, biasanya orang tua perempuan adalah pihak paling akhir yang mengetahui bahwa anaknya melakukan merarik sedangkan teman dekat perempuan menjadi orang pertama yang tahu merarik.

Meskipun orang tua tidak memberikan restu, bagi perempuan Sasak sekali melakukan merarik pantang 
untuk mundur karena gagal menikah atau tidak melanjutkan merarik ke tahapan budaya selanjutnya adalah sebuah aib terutama bagi perempuan dan keluarga perempuan. Pantang bagi perempuan yang telah dibawa kawin lari oleh laki-laki kembali ke rumah karena adanya anggapan bahwa apabila seorang perempuan kembali ke rumah dan tidak melanjutkan ke pernikahan setelah merarik mereka akan kesulitan untuk menemukan jodoh kembali dan sulit untuk menikah.

Pendapat di atas begitu kuat melekat di dalam benak Suku Sasak di Desa Nyurlembang karena realitas beberapa perempuan yang kembali ke rumah orang tuanya setelah merarik tidak jua menemukan jodoh hingga menjadi "perawan tua". Ketakutan menjadi "perawan tua" menjadi salah satu sebab perempuan di Desa Nyurlembang segera menikah di usia muda. Pantang baginya untuk kembali ke rumah. Merarik tetap harus dilangsungkan hingga prosesi nyongkolan. Keyakinan pantang kembali ke rumah setelah merarik menjadi blunder bagi perempuan Suku Sasak terutama bagi mereka yang merarik dengan lakilaki yang tidak dicintainya.

Idealnya merarik dilakukan dengan dasar suka sama suka antara lakilaki dan perempuan. Namun rupanya merarik tidak selalu dilakukan dengan cara demikian. Platt (2012: 167-174) menceritakan beberapa kisah perempuan yang melakukan merarik dengan lakilaki yang tidak dicintainya dan terpaksa merampungkan semua proses merarik karena terlanjur. Perempuan tersebut lantas memilih untuk bercerai setelah beberapa tahun mencoba bertahan di dalam pernikahan dengan laki-laki yang tidak dicintainya.

Merarik harusnya merupakan momen bagi seorang perempuan menjadi agen bagi dirinya sendiri sehingga dia bisa memutuskan laki-laki mana yang akan dinikahinya. Lantas bagaimana mungkin seorang perempuan mau merarik dengan laki-laki yang tidak dicintainya. Di Desa Nyurlembang beberapa perempuan melakukan merarik karena "dipaksa". Beberapa perempuan tersebut keluar bersama dengan laki-laki dan diajak paksa untuk merarik seketika itu juga. Merarik spontan dilakukan karena laki-laki tersebut menyenangi perempuan yang ia ajak merarik sedangkan perempuan tersebut tidak menyenangi laki-laki yang memaksanya untuk merarik. Karena perempuan tersebut tidak mungkin kembali ke rumah orang tua karena hal tersebut tabu untuk diilakukan maka merarik akan terus berjalan hingga prosesi adat selesai.

Mengingat aktor paling utama dalam merarik adalah laki-laki, teman sebayanya menjadi orang yang penting melaksanakan niat merarik. Dalam perbincangan dengan sebaya keinginan merarik dan bagaimana tradisi tersebut dijalankan merupakan hal afirmatif dan cita-cita yang dihidupkan untuk membangun sebuah keluarga di Desa Nyurlembang. Pengalaman orang tua dan pengalaman teman sebaya melakukan merarik merupakan hal yang terendap dalam alam bawah sadar berbudaya mereka. Ketika ada laki-laki yang meniatkan untuk merarik temanteman sebayanya akan dengan senang hati membantu proses tersebut meskipun perempuan yang diinginkannya tidak mencintai laki-laki tersebut. Ketika hal ini 
terjadi, agensi perempuan Sasak dalam memilih laki-laki yang akan dijadikan suaminya sama sekali tidak berlaku. Yang terjadi justru merarik menjadi celah melemahkan perempuan.

Lemahnya posisi perempuan juga terlihat atas pilihannya menyetujui merarik dengan laki-laki yang dicintainya namun tidak siap secara finansial. Bagi perempuan Sasak, menyetujui merarik dengan laki-laki yang belum siap secara finansial adalah usahanya untuk membantu laki-laki tersebut karena cinta. Karena jika harus siap secara finansial, keinginan menikah tidak akan segera terlaksana mengingat biaya untuk melangsungkan pernikahan sangat besar karena panjangnya ritual adat yang harus dilakukan. Dengan merarik keinginan untuk menikah akan mudah dilaksanakan. Merarik oleh karenanya adalah proses "memaksa" orang tua laki-laki agar menyediakan materi meskipun orang tua pihak laki-laki tidak memiliki uang dan berhutang untuk menyelesaikan prosesi adat.

Pergaulan bebas antara laki-laki dan perempuan Suku Sasak telah banyak mengkhawatirkan orang tua. Banyaknya merarik yang dilangsungkan karena perempuan telah hamil terlebih dahulu sebelum menikah telah membuat orang tua Suku Sasak menyetujui merarik yang dilakukan oleh anaknya meskipun anaknya masih berada di bawah umur (di bawah 18 tahun). Merarik lantas menjadi usaha menutupi aib karena telah hamil sebelum menikah agar pasangan dan keluarga tidak mendapatkan gunjingan dari tetangga sekitar.

Ketika proses merarik berlangsung, orang tua anak perempuan akan merasa cemas karena anaknya tidak pulang ke rumah setelah lewat batas waktu yang telah ditetapkan. Orang tua biasanya menjadi orang yang paling akhir tahu bahwa anak perempuannya melangsungkan merarik dan akan sangat terkejut terlebih ketika mereka tidak pernah mendapati anak perempuannya memiliki pasangan. Rasa kecewa muncul karena biasanya mereka mengharapkan anak perempuan mereka menyelesaikan sekolah terlebih dahulu. Tidak seperti generasi sebelumnya yang bebas dan bahkan diharapkan melakukan merarik pada usia sangat muda (bahkan ada berusia12 tahun), orang tua Suku Sasak saat ini mengharapkan pendidikan yang terbaik untuk anak perempuan mereka agar memiliki kehidupan yang lebih baik.

Ketika anak perempuan mereka tidak sesuai dengan harapan, orang tua akan kecewa dan marah dengan tindakan anak perempuannya. Budaya Sasak yang mewajibkan seorang anak menghormati, menuruti, dan meminta pendapat orang tua adalah bagian dari kewajiban anak. Sebaliknya kewajiban orang tua adalah memberikan kebijaksaan dan perlindungan kepada anak. Ketika merarik tanpa sepengetahuan orang tua dilakukan merarik lantas menjadi proses meretakkan hubungan sosial keduanya.

Konflik yang terjadi di dalam merarik tidak berakhir hanya antara orang tua perempuan dengan anaknya karena melakukan merarik tanpa sepengetahuannya orang tua padahal orang tua memiliki harapan tertentu padanya. Konflik lanjutan muncul pada saat negosiasi pesuke. Keluarga laki-laki harus membayar pesuke kepada pihak perempuan karena anak laki-lakinya telah melarikan anak perempuan mereka. Proses negosiasi pesuke ini adalah bagian 
dari tradisi dalam melangsungkan merarik.

Negosiasi ini bisa berlangsung alot karena jumlah uang yang diminta oleh keluarga perempuan tidak mampu dipenuhi oleh pihak keluarga lakilaki karena pihak keluarga perempuan meminta uang yang lebih banyak dari yang mampu dibayarkan oleh keluarga laki-laki. Namun, karena merarik tetap harus dilangsungkan segera dan tidak baik menunda pernikahan terutama terhalang jumlah pesuke maka mau tidak mau keluarga perempuan menyetujui jumlah uang yang diajukan oleh keluarga laki-laki untuk menghindarkan diri dari aib. Keluarga laki-laki dapat mengancam keluarga perempuan untuk mengembalikan anak gadis mereka jika keluarga perempuan sulit untuk negosiasi besaran pesuke. Dalam proses ini, pihak keluarga perempuan berada di posisi tawar yang lemah

Tetap berlangsungnya merarik meskipun diawali berbagai permasalahan bukanlah persoalan tuntutan budaya semata-mata. Ajaran agama yang telah menjadi bagian penting dalam budaya Sasak memainkan peranan yang tidak sederhana dalam menjaga kelangsungan tradisi ini. Wacana "telah datang jodoh" menjadi wacana yang dominan dan terus menerus dimunculkan ketika sepasang muda mudi melangsungkan merarik tanpa restu orang tua. Tuntutan melaksanakan ajaran agama Islam dengan baik menjadi faktor penting mengapa orang tua perempuan mau tidak mau menerima laki-laki yang mengajak anak perempuannya merarik meskipun dalam hati menilai bahwa anak laki-laki tersebut tidak layak untuk anak perempuannya. Kepala dusun dan tokoh agama menjadi agen yang penting dalam melanggengkan pengetahuan ini. Keduanya berperan sebagai penjaga utama struktur dan pranata tradisi merarik di Nyurlembang.

Ketika rangkaian prosesi merarik yang panjang telah selesai dilaksanakan maka kepantasan adat telah selesai dilaksanakan. Namun, konflik akan kembali muncul ketika seiring dengan berjalannya waktu ternyata menantu lakilaki tidak sesuai dengan yang diinginkan oleh orang tua perempuan entah karena permasalahan ekonomi atau kepribadian menantunya. Ketidakcocokan ini menjadi cikal bakal konflik yang berkepanjangan antara 2 keluarga. Perbedaan tingkat sosial dan ekonomi antara dua keluarga yang berujung pada sikap, pandangan, dan harapan untuk hidup yang berbeda antara menantu laki-laki dan anak perempuannya membuat permasalahan panjang dalam keluarga. Karena tuntutan dan harapan perempuan mengabdi kepada suami biasanya maka perempuan dan keluarga perempuan berada pada posisi inferior dibandingkan laki-laki dan keluarga laki-laki.

Praktik merarik saat ini terkesan sebagai upaya memaksakan kehendak pasangan yang dilakukan agar orang tua mau tidak mau menerima calon menantu mereka dan bertanggung jawab untuk menyelesaikan acara pernikahan sang anak. Orang tua Suku Sasak dituntut untuk mempersiapkan pernikahan anaknya meskipun orang tua dalam keadaan belum siap untuk menyelenggarakan pernikahan baik terkait kesiapan finansial melangsungkan perkawinan, ketidaksiapan menerima calon menantu yang tidak mereka restui, dan tidak siap melepaskan anak 
perempuan mereka menikah karena mengharapkan anak perempuan mereka menyelesaikan sekolah.

Mudahnya proses merarik ini membuat celah mudahnya bagi lakilaki untuk menikah kedua kali tanpa persetujuan istri pertama. Meskipun tidak disetujui oleh istri pertama dan keluarga perempuan yang dilarikan, merarik tetap harus dilangsungkan karena aib bagi perempuan dan keluarga perempuan jika tidak melangsungkan merarik. Pada tingkat ektrem, jika perempuan yang dilarikan adalah perempuan bersuami, maka suami perempuan tersebut dipaksa menceraikan istrinya. Kasus ini pernah terjadi di Desa Nyurlembang dimana seorang perempuan bersuami dipaksa merarik oleh seorang laki-laki. Karena aib bagi perempuan kembali ke rumah maka setelah diskusi antara keluarga perempuan, keluarga laki-laki, kepala dusun, dan tokoh agama suami perempuan tersebut yang pada saat kejadian tengah bekerja menjadi TKI di Malaysia dipaksa menceraikan istrinya.

Banyak pernikahan yang diawali merarik di Nyurlembang tidak dicatatkan di KUA. Legalitas negara atas pernikahan dianggap tidak penting oleh Suku Sasak di Nyurlembang karena pernikahan merarik telah sah menjadi ikatan bagi suami istri berdasarkan agama dan budaya. Memperoleh legitimasi agama dan budaya atas pernikahan adalah hal yang lebih penting bagi Suku Sasak di Nyurlembang dibandingkan legalitas formal negara.

Lemahnya legalitas pernikahan dalam sisi hukum negara menyebabkan posisi perempuan menjadi lebih rentan. Pertama, kondisi ini memudahkan laki-laki untuk melakukan poligami.
Isteri pertama dituntut untuk menerima pernikahan suaminya, kalaupun perempuan akhirnya menolak merarik sang suami maka satu-satunya pilihan adalah dengan jalan bercerai. Biasanya perempuan yang tetap bertahan dalam poligami ini adalah mereka yang sangat tergantung secara ekonomi pada suami, sehingga mau tidak mau harus menerima untuk dipoligami. Kedua, apabila terjadi perceraian, perempuan tidak bisa menggugat haknya, termasuk harta bersama selamaberkeluarga. Kebanyakan perempuan Suku Sasak setelah bercerai tidak lagi memperoleh nafkah, meskipun perempuan membawa serta anak-anak mereka. Begitu juga dengan harta benda, setelah bercerai biasanya perempuan tidak mendapatkan apapun dari harta yang diperoleh bersama.

Ketika legitimasi agama dan budaya menjadi lebih penting dibandingkan legalitas formal agama maka pada saat itulah Suku Sasak di Nyurlembang hanya mengandalkan sanksi budaya yang perlahan-lahan mulai kendur karena adanya banyak perubahan budaya. Budaya Sasak yang tidak kebal terhadap perubahan membuat kepastian-kepastian budaya dan perlindungan budaya menjadi lebih rapuh. Legalitas formal negara atas pernikahan dengan jalan mendaftarkan pernikahan di KUA bisa menjadi jalan terbaik untuk menopang ketidakpastian budaya tersebut dan memberikan perlindungan yang lebih baik kepada perempuan.

\section{MELAMAR BAGI SUKU SASAK DESA NYURLEMBANG}

Jika sebelumnya satu-satunya cara untuk memulai keluarga adalah dengan 
cara merarik di Desa Nyurlembang konsep dan praktik lamaran rupanya perlahan mulai diterima sebagian kecil orang yang tinggal di sana. Penerimaan perlahan konsep dan lamaran merarik ini tidak lain karena munculnya pemahaman baru yang berbeda dengan pemahaman lama mengenai lamaran itu sendiri. Jika sebelumnya lamaran dianggap sebagai proses meminta anak perempuan dan membicarakan harga di depan adalah hal yang tidak pantas dilakukan maka lamaran saat ini justru dianggap sebagai tawaran konsep dan praktik membangun keluarga yang lebih baik dibandingkan merarik mengingat banyaknya permasalahan yang terjadi karena merarik.

Di Desa Nyurlembang saat ini berkembang 2 macam merarik yaitu kawin lari dan lamaran. Merarik dengan cara kawin lari dilakukan oleh sebagian besar Suku Sasak di Desa Nyurlembang. Dalam proses ini pasangan yang melakukan merarik tidak memberitahukan waktu merarik dan calon suami/istri kepada orang tua masing-masing karena cara ini adalah bagian dari tradisi merarik yang telah dilakukan Suku Sasak sejak lama. Sedangkan merarik dengan cara melamar dilakukan oleh beberapa orang saja di desa ini. Menurut keterangan informan, dari total Suku Sasak yang tinggal di Desa Nyurlembang hanya 5 orang saja yang melakukan proses lamaran, selebihnya melakukan merarik.

Melamar merupakan hal yang baru dilakukan oleh Suku Sasak di Desa Nyurlembang dan menjadi pilihan bagi 5 orang di Desa Nyurlembang yang telah melakukan pernikahan melalui proses tersebut. Dalam proses ini, laki-laki dan keluarganya datang ke rumah keluarga perempuanuntukmenanyakankesediaan keluarga perempuan dan perempuan tersebut menjadi keluarga besar dengan mengikatkan diri pada pernikahan. Pada pernikahan yang diawali dengan lamaran, proses adat menjadi lebih ringkas karena panyeboan, selabar, majetik tidak perlu dilakukan sedangkan negoisasi pesuke dilangsungkan pada saat lamaran atau setelah lamaran. Setelah lamaran dilaksanakan, prosesi sorong serah, mbait wali, dan nyongkolan tetap dilaksanakan.

"Seperti bukan orang Sasak saja" adalahpernyataanyangseringdilontarkan oleh masyarakat Desa Nyurlembang ketika ada anggota masyarakatnya yang tidak memilih merarik untuk menikah, meskipun demikian beberapa orang tetap memilih lamaran, bukan merarik. Jika merarik selalu dilaksanakan pada malam hari, lamaran bisa dilakukan pada siang atau malam hari. Lamaran yang dilaksanakan pada siang hari seringkali menarik minat warga untuk melihatnya dari dekat. Lamaran menjadi semacam pertunjukan yang menarik untuk ditonton karena jarang dilakukan oleh Suku Sasak di Desa Nyurlembang. Hal ini seringkali membuat keluarga yang memilih melamar merasa tidak nyaman dan mendorong warga yang lainnya tetap memilih merarik karena tidak ingin menjadi pusat perhatian warga desa.

Lamaran memungkinkan keluarga perempuan dan keluarga laki-laki untuk saling mengenal terlebih dahulu, pun demikian antara orang tua dengan pasangan anak perempuan/laki-laki mereka. Konflik yang muncul karena adanya ketidakcocokan orang tua perempuan dengan calon menantu lakilaki berkurang karena hadirnya waktu dan kesempatan untuk menilai laki- 
laki yang menjadi calon suami anaknya dan keluarga laki-laki tersebut. Lakilaki yang memilih lamaran biasanya telah mempunyai persiapan finansial yang baik dan ini berimplikasi pada keberlangsungan ekonomi keluarga yang ia bangun. Dengan demikian lamaran memberikan kepastian hidup yang lebih baik bagi perempuan dan meminimalisir konflik yang timbul saat maupun setelah pernikahan berlangsung. Namun karena tidak ada unsur paksaan di dalam adat seperti ketika merarik dilakukan maka pembatalan menikah sangat dimungkinkan setelah lamaran dilakukan.

Semakin tingginya pemahaman agama Islam dan tingginya pendidikan tinggi menjadi alasan mengapa lamaran dinilai lebih baik dibandingkan merarik. Lamaran dianggap lebih dekat dengan syariat Islam dibandingkan dengan kawin lari karena syariat Islam memang mensyaratkan membangun keluarga dengan cara melamar bukan kawin lari. Lamaran juga dianggap lebih memiliki dampak positif untuk semua orang yang terlibat terutama perempuan dan keluarga perempuan karena lamaran mensyaratkan persiapan finansial dan mental laki-laki yang akan melakukannya sehingga ketidakberdayaan perempuan dan keluarga perempuan yang biasanya muncul dalam tradisi merarik hilang.

Membuat lamaran sebagai alternatif lain di Desa Nyurlembang tidaklah mudah. Selain karena dianggap bukan budaya Sasak, lamaran mensyaratkan kesiapan psikologis dan finansial terutama bagi laki-laki yang tidak mudah untuk dilakukan. Ketika lakilaki melakukan lamaran namun ditolak karena dianggap "tidak pantas" maka merarik akan tetap menjadi pilihan utama karena pernikahan akan tetap dilangsungkan apalagi jika pasangan saling mencintai. Merarik oleh karena itu tetap menjadi pilihan terbaik untuk mempercepat keinginan untuk menikah meskipun banyak permasalahan muncul darinya.

\section{KESIMPULAN}

Budaya patriarki yang begitu kuat membuat perubahan budaya merarik yang ditopang oleh teknologi modern (mobile phone), hanya memperkuat posisi laki-laki dalam melakukan merarik. Di sisi lain, perempuan tetap dituntut untuk melestarikan budaya yang sudah ada. Bahkan lamaran yang menjadi alternatif bargaining position perempuan malah dianggap "memperjualbelikan anak perempuan".

Posisi laki-laki dan perempuan yang sejak awal unequal pada Suku Sasak, ketika terjadi perubahan -dengan adanya teknologi, maka perubahan yang terjadi lebih menguntungkan laki-laki. Perempuan tetap berada pada ranah yang dituntut untuk menjaga keberlanjutan budaya. Bagian proses merarik yang bisa berubah dan tidak, ditentukan oleh pihak laki-laki dan keluarganya.

\section{DAFTAR PUSTAKA}

Adnan, S. 2004. Pergeseran Nilai-nilai Adat Marari Pada Masyarakat Suku Sasak Lombok (Studi Pada Kecamatan Ampenan, Kota Mataram, Provinsi Nusa Tenggara Barat). Tesis. Semarang: Universitas Diponegoro .

Amin, A. 1997. Adat Istiadat Daerah Nusa Tenggara Barat. Jakarta: Departemen Pendidikan dan Kebudayaan Republik Indonesia. 
Aniq, A. F. 2012. Konflik Peran Gender Pada Tradisi Merarik di Pulau Lombok. Annual International Conference on Islamic Studies (AICIS XI). Jakarta: Kementrian Agama. hal. 2321-2339.

Daliem, M. M. 1982. Lombok Selatan Dalam Pelukan Adat Istiadat Sasak. Mataram: Departemen Pendidikan dan Kebudayaan.

Hamdi, S. 2017. Potret Perempuan Sasak Migrasi Perempuan Sasak Pernikahan Dini dan Legitimasi Kekerasan Simbolik Terhadap Perempuan Dalam Budaya Sasak, dalam http://www. alidachlancenter.com/(diakses 12 April 2017).

Haq, H. S., \& Hamdi. 2016. Perkawinan Adat Merariq dan Tradisi Selabar di Masyarakat Suku Sasak. Perspektif Vol. XXI No 3 September, 157-167.

Murdan. 2015. Perkawinan Masyarakat Adat (Studi Proses Perkawinan Masyarakat Muslim Suku Sasak Dalam
Perspektif Antropologi Hukum). Tesis. Yogyakarta: UIN Sunan Kalijaga.

Parlindungan, T. 2004. Budaya Kawin Lari dan Akibat Hukumnya Pada Masyarakat Suku Lampung Pepadun di Kecamatan Negeri Sakti Kabupaten Tanggamus Provinsi Lampung. Tesis. Semarang: Universitas Diponegoro.

Platt, M. 2012. Sudah Terlanjur: "Perempuan dan Transisi ke Perkawinan di Lombok". Jurnal Studi Pemuda, Volume 1 No 2: 165-178.

Rabiatul, A. 2016. Makna Tradisi Merarik (Studi Tentang Bertahannya Tradisi Merarik di Desa Nyurlembang Kecamatan Narmada Kabuaten Lombok Barat). Skripsi. Malang: Universitas Brawijaya.

Saladin, B. 2013. Tradisi Merari' Suku Sasak di Lombok Dalam Perspektif Hukum Islam. Al Ihkam, Volume 8 No 1: 21-39. 